1 Title: Improved CD4 T-cell profile and inflammatory levels in HIV-infected subjects

2 on maraviroc-containing therapy is associated with better responsiveness to HBV

3 vaccination.

4 Authors: Inés Herrero-Fernéndez ${ }^{1}$, Isaac Rosado-Sánchez ${ }^{1}$, Miguel Genebat ${ }^{1}$, Laura

5 Tarancón-Díez ${ }^{1}$, María Mar Rodríguez-Méndez ${ }^{1}$, María Mar Pozo-Balado, Carmen

6 Lozano $^{2}$, Ezequiel Ruiz-Mateos ${ }^{1}$, Manuel Leal ${ }^{1,3^{*}}$, Yolanda M. Pacheco ${ }^{1 * \#}$

\title{
7 Affiliation:
}

$8{ }^{1}$ Institute of Biomedicine of Seville (IBiS), Virgen del Rocío University Hospital 9 (HUVR)/CSIC/University of Seville, Seville, Spain

$10{ }^{2}$ Microbiology Service, Virgen del Rocío University Hospital (HUVR), Seville, Spain

$11{ }^{3}$ Internal Medicine Service, Viamed Sta. Ángela Hospital, Seville, Spain

$12 *$ Equal contribution

13 Running title: Impact of MVC-containing therapy

14 Text word count: 2822

15 Abstract word count: 250

16 Number of inserts: 5 (3 tables and 2 figures)

\section{Number of references: 42}

18 Keywords: Maraviroc (MVC), CD4 T-cell, activation, Treg, CRP, inflammation, HBV

19 vaccine, dendritic cells (DC), recent thymic emigrants (RTE)

\section{Corresponding Author:}

21 \#Address to correspondence and reprints: 
bioRxiv preprint doi: https://doi.org/10.1101/298521; this version posted April 10, 2018. The copyright holder for this preprint (which was not certified by peer review) is the author/funder. All rights reserved. No reuse allowed without permission.

23 Laboratory of Immunology, Institute of Biomedicine of Seville (IBiS)/UGC Clinical

24 Laboratories, Virgen del Rocío University Hospital, Avda. Manuel Siurot s/n. PC

25 41013, Seville, Spain. Email: ypacheco-ibis@us.es. 


\section{ABSTRACT}

Introduction: We previously found that a maraviroc-containing combined antiretroviral therapy (MVC-cART) was associated with a better response to the Hepatitis B Virus (HBV) vaccine in HIV-infected subjects younger than 50 years old. We aimed here to extend our previous analysis including immunological parameters related to inflammation, T-cell and dendritic cell (DC) subsets phenotype and to explore the impact of MVC-cART on these parameters.

Methods: We analyzed baseline samples of vaccinated subjects under 50 years old $(\mathrm{n}=41)$. We characterized CD4 T-cells according to the distribution of their maturational subsets and the expression of activation, senescence and prone-to-apoptosis markers; we also quantified Treg-cells and main DC subsets. Linear regressions were performed to determine the impact of these variables on the magnitude of vaccine response. Binary logistic regressions were explored to analyze the impact of MVC-cART on immunological parameters. Correlations with the time of MVC exposure were also explored.

Results: MVC-cART remained independently associated with HBV-vaccine responsiveness even after adjusting by immunological variables. The $\% \mathrm{CD} 4^{+} \mathrm{CD} 25^{\mathrm{hi}} \mathrm{FoxP}^{+}{ }^{+} \mathrm{ki} 67^{+}$and $\% \mathrm{pDCs}$ were also independently associated. Moreover, HIV-infected subjects on MVC-containing therapy prior to vaccination showed lower inflammatory levels, activated CD4 T-cells and frequency of Treg cells and higher frequency of recent thymic emigrants.

Conclusion: Treg-cell levels negatively impacted the HBV-vaccine response, whereas higher pDCs levels and a MVC-cART prior to vaccination were associated with better responsiveness. These factors together with the improved phenotypic CD4 T-cell profile 
bioRxiv preprint doi: https://doi.org/10.1101/298521; this version posted April 10, 2018. The copyright holder for this preprint (which was not certified by peer review) is the author/funder. All rights reserved. No reuse allowed without permission.

50 and the lower inflammatory levels found in subjects with a MVC-cART prior HBV

51 vaccination could contribute to their enhanced vaccine response. 


\section{INTRODUCTION}

Human Inmunodeficiency Virus (HIV)-infected subjects are at high risk for Hepatitis B Virus (HBV) infection and progression of severe, life-threatening hepatic complications, as cirrhosis and hepatocellular carcinoma [1, 2]. To prevent the associated morbimortality, worldwide current guidelines recommend vaccination against $\mathrm{HBV}$ in all HIV-infected subjects susceptible to be coinfected by HBV, but the response rates are lower than in HIV non-infected subjects [reviewed in 3].

The best known predictors of vaccine efficacy are undetectable viral load and CD4 Tcell counts above 350 cells $/ \mathrm{mm}^{3}$ [3]. Thus, it is well assumed that a successful combined antiretroviral therapy (cART) favors the vaccine response, however, the influence of the type of antiretroviral treatment has been scarcely explored until now. In this line, it was first described that maraviroc (MVC), a CCR5 antagonist, enhanced meningococcal neo-immunization and accelerated the response to tetanus boost [4]. More recently, we have also reported that a MVC-containing cART (MVC-cART) was associated with a better response against the HBV vaccine, at least in subjects younger than 50 years old [5]. Nevertheless, the potential subjacent mechanisms were unaddressed.

Different antiretroviral combinations including MVC, have comparatively proved their beneficial effects on the levels of inflammatory biomarkers [6] and the T-cell immunophenotype [7]. In two clinical trials, an improvement of duodenal immunity and a reduction in bone loss has been associated to such combinations $[8,9]$. Furthermore, MVC on monotherapy also reduced the frequency of regulatory T-cells (Treg) in antiretroviral-naïve subjects [10], even improving the distribution of Treg subsets [11]. This could be relevant since we observed that regulatory $\mathrm{T}$ cells (Treg) negatively impacted the HBV vaccine responsiveness in a previous cohort [12]. Possibly, MVC 
76 could enhance different functions required to mount an effective response following

77 HBV vaccination including antigen-presentation, T-cell help, regulatory T-cell

78 suppression and B cell functions $[13,14]$.

79 In the present work, we extended our previous analysis [5] including several relevant

80 immunological variables to gain knowledge about the factors impacting the

81 responsiveness to the $\mathrm{HBV}$ vaccine. We additionally explored the potential effect of a

82 MVC-cART exposure on different parameters related to inflammation, T-cell function

83 and DC subsets that could account for the effectiveness of the HBV vaccination. 


\section{RESULTS}

\section{Demographic, clinical and immunological variables associated with the magnitude}

\section{of HBV vaccine responsiveness}

We extended our previous analysis including demographic and clinical variables [5], adding several relevant immunological variables to explore to what extent each of these factors could impact the magnitude of the response. Around half of the population (51\%) was receiving a MVC-cART, consisting of MVC and a boosted protease inhibitor (PI) or MVC and two nucleoside-reverse transcriptase inhibitors (NRTIs).

As shown in Table 1, sex, previous AIDS, MVC-containing-cART, previous HBV vaccination, simultaneous HAV vaccination, hsCRP, $\% \mathrm{CD}^{+}{ }^{\mathrm{ki}} 67^{+}$,

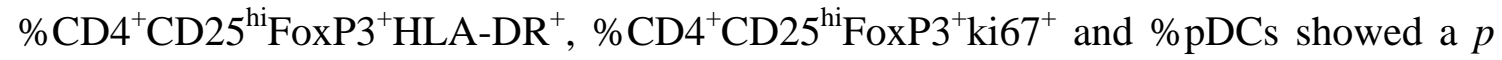
value $<0.1$ in the univariate analyses, thus, were all introduced in the multivariate model. In this model, the unique variable showing independent association was MVCcontaining-cART, with a borderline significance $(p=0.059$; B [95\% CI], $243.4[-10.2-$ 504.9]). Next, we explored a stepwise forward multivariate analysis. In this model, the only variables included were MVC-containing-cART ( $p=0.016$; B [95\% CI], 293.3 $[58.1-5280.5]), \% \mathrm{CD}^{+} \mathrm{CD} 25^{\mathrm{hi}} \mathrm{FoxP}^{+} \mathrm{ki}^{+}(p=0.005, \mathrm{~B}[95 \% \mathrm{CI}],-29.5$ [-49.6-9.5]) and \%pDCs (p=0.009, B [95\% CI], 1961.2 [530.4-3392.1]) (Table 1), which were independently associated with the magnitude of response. Interestingly, the association was negative with the $\% \mathrm{CD} 4^{+} \mathrm{CD} 25^{\mathrm{hi}} \mathrm{FoxP} 3^{+}$ki $67^{+}$but positive with the MVCcontaining-cART and \%pDCs.

Demographic, clinical and immunological variables associated with a MVCcontaining cART 
108 We compared the demographic, clinical and immunological variables, at the moment of vaccination, between patients receiving a MVC-cART or a MVC-sparing-cART (Table 2). The age, $\mathrm{CD} 4^{+} / \mathrm{CD}^{+}$ratio, time on HIV-treatment, $\% \mathrm{CD} 4^{+} \mathrm{RTE}$ and $\% \mathrm{mDCs}$ showed a $p$ value $<0.1$ in the univariate analyses and were, therefore, included in the multivariate analysis. To note, $19 \%$ of the subjects treated with MVC-cART were also receiving NRTIs, whereas the $70 \%$ of the subjects on a MVC-sparing-cART were receiving NRTIs (Table 2). Thus, the absence of NRTIs was highly colineal with the presence of MVC and was not included for adjustment. As it is shown, the \%CD4 ${ }^{+} \mathrm{RTE}$ $(p=0.024 ; \mathrm{OR}[95 \% \mathrm{CI}], 1.20[1.02-1.41])$ and \%mDCs $(p=0.048 ; \mathrm{OR}[95 \% \mathrm{CI}], 0.16$ [0.02-0.98]) were independently associated with a MVC-cART, whereas $\mathrm{CD}^{+} / \mathrm{CD}^{+}$ ratio $(p=0.086$; OR $[95 \% \mathrm{CI}], 0.19$ [0.03-1.26]), showed association with borderline significance.

Relationship between the time of exposure to a MVC-containing cART and immunological variables

We observed a high variability on the time of exposure to the MVC-cART previous to vaccination (median [IQR], 16 [5-38] months). Thus, we explored if this could have affected its impact on immunological variables. This analysis was logically restricted to the MVC-cART group $(\mathrm{N}=21)$. We observed negative correlations between the time of exposure to MVC-cART and the $\% \mathrm{CD}^{+}{ }^{+} \mathrm{ki} 67^{+}(\mathrm{r}=-0.477, p=0.029)$, the $\% \mathrm{CD} 4^{+} \mathrm{HLA}-$ $\mathrm{DR}^{+}(\mathrm{r}=-0.489, p=0.034)$ and the $\% \mathrm{CD}^{+} \mathrm{CD} 25^{\mathrm{hi}} \mathrm{FoxP}^{+}(\mathrm{r}=-0.523, p=0.015)$ (Table 3 and Figure 1).

\section{Associations between the hsCRP and T-cell immunological variables}

We finally explored potential correlations between the inflammation-related marker 
132 gain insight into both, the significance of inflammatory levels in the HBV vaccine

133 responsiveness and the potential impact of a MVC-cART in such levels. The hsCRP

134 inversely correlated with $\% \mathrm{CD} 4^{+} \mathrm{RTE} \quad(\mathrm{r}=-0.326 ; p=0.049)$, whereas positively

135 correlated with activation-related markers as $\% \mathrm{CD} 4^{+} \mathrm{CD} 25^{\mathrm{hi}} \mathrm{FoxP} 3^{+} \mathrm{HLA}-\mathrm{DR}^{+}(\mathrm{r}=0.468$;

$136 p=0.003), \quad \% \mathrm{CD} 4^{+} \mathrm{HLA}_{-\mathrm{DR}}{ }^{+} \quad(\mathrm{r}=0.316 ; p=0.057)$ and $\% \mathrm{CD} 4^{+} \mathrm{CD} 25^{\mathrm{hi}} \mathrm{FoxP} 3^{+} \mathrm{ki}^{+}$

$137(\mathrm{r}=0.315 ; p=0.054)$, though these two last associations showing borderline significance

138 (Figure 2). 
We recently reported a beneficial effect of a MVC-cART in the response to the HBV vaccine in HIV-infected subjects younger than 50 years old [5]. We extended here this analysis and, after adjustment by baseline immunological variables, the effect of the MVC-cART remained independently associated. Additionally, a negative effect of Treg cells and a beneficial effect of pDC were also observed. Furthermore, being on a MVCcART prior to vaccination was associated with an improved immunological profile. Such profile included lower inflammatory levels, activated CD4 T-cells and frequency of Treg and higher frequency of RTE.

In the response to the HBV vaccine, a peptide antigen administered intramuscularly, the helper CD4 T-cell function plays a major role $[13,14]$ and it is well assumed that T-cell exhaustion and senescence related to HIV infection may result in the failure of such response [15]. The involvement of Treg cells in several immunization models is also being studied $[16,17,18]$. The rationale is that Treg cells suppress the proliferation and cytokine secretion of CD4, CD8 T cells and monocytes, dendritic and B cells [19, 20]. In fact, Treg cells were found within germinal centers of human lymphoid tissues suppressing the B cell immunoglobulin class switching needed to mount a properly antibody response [21]. Importantly, HIV-infected subjects show higher frequency of Treg-cells in peripheral blood compared to healthy donors [22], and we already found a negative role of Treg cells in the response to HBV vaccine in a previous cohort of HIVinfected subjects [12]. Now, in this cohort, we also found the frequency of Treg, particularly those activated/proliferating $\left(\mathrm{CD} 4^{+} \mathrm{CD} 25^{\mathrm{hi}} \mathrm{FoxP} 3^{+} \mathrm{ki} 67^{+}\right), \quad$ inversely associated to the magnitude of the vaccine response. Reasonably, the fraction of a positive association of vaccine responsiveness with the frequency of pDC. Globally, 
164 DC are a connection between the innate and adaptive immune system, playing an essential role against pathogens and during vaccination, that are being already targeted for improvement of HBV vaccine responsiveness [23, 24, 25]. Particularly, pDC are a unique DC subset that specializes in the production of type I interferons promoting antiviral responses and are also able to induce $\mathrm{T}$ helper $1 \mathrm{CD} 4$ responses [26], what reasonably explains their contribution in the improvement on $\mathrm{HBV}$ vaccine responsiveness.

Also importantly, plasma levels of soluble inflammatory markers before vaccination negatively predicted responses to $\mathrm{HAV}, \mathrm{HBV}$, and tetanus vaccines in $\mathrm{HCV}$ and $\mathrm{HIV}$ infection [27]. Moreover, CRP levels were a significant predictor of herpes zoster vaccine response in elderly nursing home residents [28]. In our cohort, we observed only a borderline negative association between the hsCRP levels and the vaccine responsiveness, but these levels correlated with the frequency of

$177 \mathrm{CD}^{+} \mathrm{CD} 25^{\mathrm{hi}} \mathrm{FoxP}^{+}{ }^{+} \mathrm{ki}^{+}$, a key factor in relation to the vaccine responsiveness.

Antiretroviral treatment partially restores the immunodeficiency related to HIV infection, improving antigen-specific T-cell responses and recovering T-cell repertoire [29]. In fact, the duration of cART was associated with the HBV vaccine response [30]. However, the specific effects of different antiretroviral families have been less studied. It is reasonable to expect a negative impact of nucleoside reverse-transcriptase inhibitors (NRTI), since they affect cellular senescence through inducing accelerated shortening of telomeres in peripheral T-cells [31]. In fact, telomere length has been associated to the response to influenza vaccine in elderly non HIV-infected subjects [32]. Moreover, we have recently found a better profile of T-cells, regarding biomarkers of cell survival (CD127) and replicative senescence (CD57), in subjects on NRTIsparing regimens [33]. In contrast, MVC positively impacted the response to different 
vaccine antigens in HIV-infected subjects $[4,5]$, although the mechanisms involved in such effect have not been yet explored.

191 We have now explored the immunological profile associated with a MVC-cART in the context of the HBV vaccine response, including several markers of CD4 T-cell activation, senescence and susceptibility to apoptosis, as well as Treg cells and DC subsets. HIV-infected subjects with such therapy at the moment of vaccination showed better characteristics of their CD4 T-cell pool, with a less activated phenotype, a higher contribution of RTE and a lower frequency of Treg cells. Noteworthy, vaccine responsiveness was mostly associated to these factors in others cohorts. Thus, a better response has been predicted in relation with a lower activation of T-cells [34], a higher frequency of CD34+ precursors [35, 36] and a lower frequency of Treg [12]. Interestingly, we previously showed an effect of MVC in reducing Treg in antiretroviral-naïve subjects [10]. In the present cohort of cART-experienced subjects, the frequency of Treg was decreased with increasing time of exposure to a MVC-cART. Since both cohorts differed very much, not only in therapeutic parameters but also in age or time from diagnosis among other factors, this finding empowers the immunomodulatory properties of MVC through reducing Treg cells. Regarding the possible effect of MVC-cART on inflammatory levels, we failed to observe a direct association with hsCRP levels in our cohort, but we cannot exclude a potential effect of MCV-cART on other inflammatory cytokines, as previously reported [6]. Moreover, hsCRP was inversely associated with the frequency of RTE and positively associated with T-cell activation markers, suggesting also a potential indirect impact of MVC on 211 the inflammatory state.

212 Ideally, we should have included more subjects to improve the power of our analyses, however, we had to restrict our analyses to the population younger than 50 years old 
214 because of the higher effect of MVC-cART on the vaccine responsiveness in this population [5]. In fact, we observed a higher impact of MVC-cART on the studied immunological parameters in this age-restricted population (data not shown). It is reasonable to speculate that the added age-associated immunodeficiency could limit or mask the potential benefits of such antiretroviral therapy on the immunological profile. Accordingly, the immunosenescence, which compromises HBV vaccine responsiveness [14], is accentuated or presents unique features in an HIV-infection scenario [37, 38]. On the other hand, it is well-known that age limits HBV vaccine responsiveness [39]. Interestingly, the group on MVC-cART showed a lower CD4/CD8 ratio, which has been reported to negatively impact vaccine response [40]. This could be due to the lower period of treatment in this group, critical for the CD4/CD8 T-cell ratio normalization [41]. In any case, despite the lower CD4/CD8 ratio, the group on MVCcART showed better vaccine responsiveness and CD4 T-cell profile. Finally, we cannot discriminate among the particular effects due to the presence of MVC or to the absence of NRTIs in the cART and thus, we can only conclude about the beneficial effects of such combined therapy. In accordance, similar combined therapies (NRTI-free) are being explored in the clinical setting in an attempt to reduce toxicities and to improve immune reconstitution [42].

In summary, in this extended analysis, MVC-cART remained independently associated to a better $\mathrm{HBV}$ vaccine responsiveness in subjects younger than 50 years, but other immunological factors as Treg and pDC also showed a key role. This could focus further research on the mechanisms involved to find out novel therapeutic targets that could improve such responsiveness. We also report that MVC-cART was associated with a less activated CD4 T-cell profile, with higher levels of RTE and a lower frequency of Treg. Further research would give complementary information about the 
bioRxiv preprint doi: https://doi.org/10.1101/298521; this version posted April 10, 2018. The copyright holder for this preprint (which was not certified by peer review) is the author/funder. All rights reserved. No reuse allowed without permission.

239 potential benefit of the instauration of similar combined antiretroviral therapies before

240 initiating vaccination protocols with the aim of improved responsiveness. 


\section{Study design, patients and samples}

244 The vaccination protocol has been reported elsewhere [5]. Briefly, HIV-infected subjects from the Virgen del Rocío University Hospital were consecutively vaccinated against HBV. These subjects: a) were on suppressive cART (at least in the last 6 months), b) had CD4 T-cell populations of $>300$ cell counts/ $\mu 1, c)$ negative serology for HBsAg and anti-HBc and d) anti-HBs titers of $\leq 10 \mathrm{mIU} / \mathrm{ml}$. The vaccination protocol consisted of 3 intramuscular double doses $(40 \mu \mathrm{g})$ of the recombinant Engerix-B vaccine (GlaxoSmithKline, Brentford, United Kingdom) at 0, 1, and 3 months. The vaccine response was measured 6 months after the first dose. A group of subjects was simultaneously vaccinated at 0 and 6 months against Hepatitis A Virus (HAV) (simultaneous HAV vaccination) with two intramuscular doses of the vaccine Havrix1440 (GlaxoSmithKline, Brentford, United Kingdom). This subgroup of subjects had a previous negative serology for HAV. Fresh blood samples were collected at baseline, just before the administration of the first vaccine dose. All patients gave informed consent to enter the study which was approved by the Ethic Committee of our Hospital. We restricted the present analyses to subjects younger than 50 years old $(n=41)$ from the total population because the beneficial effect of a MVC-cART on the vaccine response was observed in this population [5].

\section{Laboratory measurements}

262 Absolute numbers of CD4 and CD8 T cells and percentages of lymphocytes, monocytes and neutrophils were determined with an Epics XL-MCL flow cytometer (BeckmanCoulter). Plasma HIV-1 RNA levels were measured using quantitative PCR (Cobas with a detection limit of $20 \mathrm{HIV}-\mathrm{RNA}$ copies/ml. Plasma samples were tested for HBV- 
267 related markers ( $\mathrm{HBsAg}$, anti-HBs, and anti-HBc) using an $\mathrm{HBV}$ enzyme-linked

268 immunosorbent assay (ELISA; Siemens Healthcare Diagnosis, Malvern, PA).

269 Qualitative PCR amplification was used for plasma HCV amplification (Cobas

270 Amplicor; Roche Diagnosis, Mannheim, Germany), with a detection limit of $15 \mathrm{IU} / \mathrm{ml}$.

271 The high sensitive $\mathrm{C}$ reactive protein (hsCRP) levels were determined with an

272 immunoturbidimetric serum assay, using Cobas 701 (Roche Diagnostics, Mannheim,

273 Germany).

\section{Flow cytometry}

275 Peripheral blood mononuclear cells (PBMCs) were isolated from fresh blood before the

276 first dose of vaccine and cryopreserved. For the immunophenotyping of cellular subsets,

277 PBMCs were thawed and immediately stained with surface antibodies: anti-CD31 PE-

278 CF594, anti-CD56 BV510, anti-CD25 BV605, anti-CD45RA BV650, anti-CD4 BV786,

279 anti-CD3 APC-H7, Lin2 FITC (anti-CD3, anti-CD19, anti-CD20, anti-CD14 and anti-

280 CD56), anti-CD11c BV650, anti-HLA-DR BV711 (BD biosciences, USA), anti-CD39

281 FITC, anti-CD57 PE-Cy7, anti-OX40 BV421, anti-HLA-DR BV570, anti-CD95

282 BV711, anti-CD27 AF700 (BioLegend, USA) and anti-CD123 AF700 (R\&D, San

283 Diego CA, USA). When necessary for intracellular staining, cells were fixed and

284 permeabilized according to the manufacturer's instructions (FoxP3/Transcription Factor

285 Staining Buffer, Ebioscience, USA), and stained with intracellular antibodies: anti-ki67

286 PerCP-Cy5.5, anti-FoxP3 PE and anti-CTLA-4 APC (BD Biosciences, USA).

287 Isotype controls for CD39, CD31, OX40, CD25, CD95, ki67, FoxP3 y CTLA4 were 288 included in each experiment.

289 We characterized peripheral CD4 T-cells according to the distribution of their 290 maturational subsets [naïve $\left(\mathrm{CD} 27^{+} \mathrm{CD} 45 \mathrm{RA}^{+}\right)$, central memory $\left(\mathrm{CD} 27^{+} \mathrm{CD} 45 \mathrm{RA}^{-}\right)$, 291 effector memory (CD27 $\left.{ }^{-} \mathrm{CD}^{2} \mathrm{RA}^{-}\right)$and TemRA (CD27 $\left.{ }^{-} \mathrm{CD} 45 \mathrm{RA}^{+}\right)$], also including 
292 Recent Thymic Emigrants (RTE; naïves $\mathrm{CD} 31^{+}$) and the expression of activation markers (HLA-DR, Ki67), senescence marker (CD57) and prone-to-apoptosis marker (CD95). We also identified Treg with classical markers $\left(\mathrm{CD} 25^{\mathrm{hi}} \mathrm{FoxP} 3^{+}\right)$and their expression of the mentioned activation markers but also of functional markers (CD39, CTLA-4). We immunophenotyped myeloid dendritic cells (mDCs) as Lin2-HLA$\mathrm{DR}^{+} \mathrm{CD} 123^{-} \mathrm{CD} 11 \mathrm{c}^{+}$and plamacytoid dendritic cells (pDCs) as Lin2 ${ }^{-} \mathrm{HLA}-\mathrm{DR}{ }^{+} \mathrm{CD} 11 \mathrm{c}^{-}$ $\mathrm{CD} 123^{+}$.

Viable cells were identified using LIVE/DEAD fixable Aqua Blue Dead Cell Stain (Life Technologies, USA). One million cells of each sample were stained, and a minimum of 100,000 events of total lymphocytes and 150,000 dendritic cells were acquired. Flow cytometry was performed on a LSR Fortessa (BD Biosciences, USA). Analysis was performed using FlowJo version 9.3 (Tree Star).

\section{Statistical analysis}

Continuous variables were expressed as medians and interquartile ranges [IQR] and categorical variables as the number of cases and percentages. Linear regressions were performed to determine factors associated with the magnitude of response (absolute anti-HBs titer). Binary logistic regressions were explored to analyze the potential impact of a MVC-cART in the clinical and immunological parameters. Variables with a

$310 p$ value $<0.1$ in the univariate analysis were considered in multivariable models.

311 Correlations were assessed using the Spearman's rho correlation coefficient. A $p$ value of $<0.05$ was considered statistically significant. Statistical analysis was performed generated using Prism (version 5, GraphPad Software, Inc.). 


\section{ACKNOWLEDGEMENTS}

316 This study was funded by grants from the Fondo de Investigación Sanitaria [FIS;

317 PI14/01693; PI16/00684], co-funded by Fondos Europeos para el Desarrollo Regional

318 (FEDER), and the Junta de Andalucía, Consejería de Economía, Innovación, Ciencia y

319 Empleo [Proyecto de Investigación de Excelencia; CTS2593]. The Spanish AIDS

320 Research Network of Excellence also supported this study (RD16/0025/0019). I.H-F

321 and I.R-S were supported by an investigator sponsored research grant from ViiV

322 Healthcare S.L. (grant number 205644). YM.P and E.R-M. were supported by the

323 Consejería de Salud y Bienestar Social of Junta de Andalucía through the "Nicolás

324 Monardes" program [C-0013-2017 and C-0032-2017, respectively]. L.T-D. was

325 supported by Instituto de Salud Carlos III [PFIS program; FI00/00431]. The funders had

326 no role in study design, data collection and interpretation, or the decision to submit the

327 work for publication.

328 The authors express their most sincere thanks to all the subjects included in the study 329 and to HIV Biobank of the Spanish AIDS Research Network. We thank also Magdalena

330 Rodriguez and Marien Gutierrez Sancho for their assistance at the Day Care Hospital

331 (Infectious Diseases Department) and to $\mathrm{M}^{\mathrm{a}}$ Antonia Abad and Marta de Luna for their 332 technical assistance and to Juan Manuel Praena for statistical assistance.

\section{TRANSPARENCY DECLARATIONS}

334 Authors declare no conflict of interest. 


\section{REFERENCES}

1. Thio CL. 2009. Hepatitis B and human immunodeficiency virus coinfection.

337 Hepatology 49 (5 suppl): S138-45.

2. Clifford GM, Rickenbach M, Polesel J, Dal Maso L, Steffen I, Ledergerber B, Rauch

A, Probst-Hensch NM, Bouchardy C, Levi F, Franceschi S; Swiss HIVCohort. 2008. Influence of HIV-related immunodeficiency on the risk of hepatocellular carcinoma. AIDS 18;22(16):2135-2141.

3. Whitaker JA, Rouphael NG, Edupuganti S, Lai L, Mulligan MJ. 2012. Strategies to increase responsiveness to hepatitis B vaccination in adults with HIV-1. Lancet Infect Dis 12:966-976.

4. Westrop SJ, Moyle G, Jackson A, Nelson M, Mandalia S, Imami N. 2012. CCR5 antagonism impacts vaccination response and immune profile in HIV-1 infection. Mol Med 18:1240-1248.

5. Herrero-Fernández I, Pacheco YM, Genebat M, Rodriguez-Méndez MDM, Lozano

Mateos E, Leal M. 2017. Association between a Suppressive Combined Antiretroviral Therapy Containing Maraviroc and the Hepatitis B Virus Vaccine Response. Antimicrob Agents Chemother. 62(1). pii:e02050-17.

6. Romero-Sánchez MC, Alvarez-Ríos AI, Bernal-Morell E, Genebat M, Vera F, Benhnia MR, Bravo-Urbieta J, Galera-Peñaranda C, de Pablo-Bernal RS, Abad-Carrillo 
357 CD40L and soluble CD14 after switching previously treated HIV-infected patients to an NRTI-sparing dual therapy. Antiviral Res 111:26-32.

7. Romero-Sánchez MC, Machmach K, Gonzalez-Serna A, Genebat M, Pulido I,

García-García M, Alvarez-Ríos AI, Ferrando-Martinez S, Ruiz-Mateos E, Leal M.

2012. Effect of maraviroc on HIV disease progression-related biomarkers. Antimicrob Agents Chemother 56:5858-5864.

8. Serrano-Villar S, Sainz T, Ma ZM, Utay NS, Wook-Chun T, Mann S, Kashuba AD, combined CCR5/integrase inhibitors-based regimen on mucosal immunity in HIVinfected patients naïve to antiretroviral therapy: A pilot randomized trial. PLoS Pathog 12:e1005540.

9. Taiwo BO, Chan ES, Fichtenbaum CJ, Ribaudo H, Tsibris A, Klingman KL, Eron Group A5303 Study Team. 2015. Less bone loss with maraviroc-versus tenofovircontaining antiretroviral therapy in the AIDS Clinical Trials Group A5303 Study. Clin Infect Dis 61:1179-1188. G, Rodríguez-Méndez MM, Vidal F, Muñoz-Fernández MA, Pacheco YM, Leal M. 2014. Maraviroc reduces the regulatory T-cell frequency in antiretroviral-naive HIV377 infected subjects. J Infect Dis 210:890-898. 
Maraviroc contributes to the restoration of the homeostasis of regulatory T-cell subsets

in antiretroviral-naive HIV-infected subjects. Clin Microbiol Infect 22:461.e1-5.

12. Pozo-Balado MM, Leal M, Méndez Lagares G, Mata RC, López-Cortés LF, Viciana

P, Pacheco YM. 2010. Increased regulatory $\mathrm{T}$ cell counts in HIV-infected

nonresponders to hepatitis B virus vaccine. J Infect Dis 202:362-369.

13. Egea E, Iglesias A, Salazar M, Morimoto C, Kruskall MS, Awdeh Z, Schlossman

SF, Alper CA, Yunis EJ. 1991. The cellular basis for lack of antibody response to

14. Filion LG, Saginur R, Szczerbak N. 1988. Humoral and cellular immune responses

by normal individuals to hepatitis B surface antigen vaccination. J Exp Immunol

71:405-409.

15. Yao ZQ, Moorman JP. 2013. Immune Exhaustion and Immune Senescence: Two

Distinct Pathways for HBV Vaccine Failure During HCV and/or HIV Infection Arch

Immunol Ther Exp 61:193-201.

16. Toka FN, Suvas S, Rouse BT. 2004. $\mathrm{CD}^{+} \mathrm{CD} 25^{+} \mathrm{T}$ cells regulate vaccine-

type 1. J Virol 78(23):13082-13089.

B, Jacobs T. 2014. Depletion of regulatory $\mathrm{T}$ cells augments a vaccine-induced $\mathrm{T}$ effector cell response against the liver-stage of malaria but fails to increase memory.

$400 \quad$ PLoS One 12;9(8):e104627. 
403 antiviral immunity against acute influenza virus infection. Mucosal Immunol doi: 10.1038/s41385-018-0004-9.

19. Miyara M, Sakaguchi S. 2007. Natural regulatory $T$ cells: mechanisms of suppression. Trends Mol Med 13:108-116.

20. Tiemessen MM, Jagger AL, Evans HG, van Herwijnen MJ, John S, Taams LS. 2007. $\mathrm{CD} 4^{+} \mathrm{CD} 25^{+}$Foxp $3^{+}$regulatory $\mathrm{T}$ cells induce alternative activation of human monocytes/macrophages. Proc Natl Acad Sci USA 104:19446-19451.

21. Lim HW, Hillsamer P, Banham AH, KimCH. 2005. Cutting edge: direct suppression of B cells by CD4+CD25+ regulatory T cells. J Immunol 175:4180-4183.

22. Suzuki Y, Gatanaga H, Oka S. 2009. High frequency and proliferation of

413 CD4+ FOXP3+ Treg in HIV-1-infected patients with low CD4 counts. Eur J Immunol 39:301-309.

23. Wang Y, Wu S, Wang ZC, Zhu XM, Yin XT, Gao K, Du ZY, Chen GZ, Yu JY. 2016. Enhanced immunity and antiviral effects of an HBV DNA vaccine delivered by a DC-targeting protein. J Viral Hepat 23(10):798-804. Development of a more efficient hepatitis B virus vaccine by targeting hepatitis B virus preS to dendritic cells. Vaccine 20;34(4):516-522. response to hepatitis $\mathrm{B}$ virus (HBV) vaccine can be upregulated by $\mathrm{CpG}$ 424 oligonucleotides complexed with Dectin-1 ligand. J Viral Hepat 24(2):155-162. 
Activation of influenza virus-specific $\mathrm{CD}^{+}$and $\mathrm{CD}^{+} \mathrm{T}$ cells: a new role for

427 plasmacytoid dendritic cells in adaptive immunity. Blood 1;101(9):3520-3526.

27. Shive

CL, Judge

CJ, Clagett

B, Kalayjian

RC, Osborn

M, Sherman

KE, Fichtenbaum

C, Gandhi

RT, Kang

M, Popkin

DL, Sieg SF, Lederman

MM, Rodriguez B, Anthony DD. 2018. Pre-vaccine plasma levels of soluble

inflammatory indices negatively predict responses to HAV, HBV, and tetanus vaccines in HCV and HIV infection. Vaccine 25;36(4):453-460.

28. Verschoor CP, Lelic A, Parsons R, Evelegh C, Bramson JL, Johnstone J, Loeb MB,

Bowdish DME. 2017. Serum C-Reactive Protein and Congestive Heart Failure as

Residents. J Infect Dis 15;216(2):191-197.

JA, Miedema. 2008. Restoration of the CD4 T cell compartment after long-term highly active antiretroviral therapy without phenotypical signs of accelerated immunological aging. J Immunol 181:1573-1581.

30. Overton ET, Sungkanuparph S, Powderly WG, Seyfried W, Groger RK, Aberg JA. 2005. Undetectable plasma HIV RNA load predicts success after hepatitis B vaccination in HIV-infected persons. Clin Infect Dis 41:1045-1048. 
inhibitors: a potential factor contributing to HIV-associated accelerated aging. J Infect Dis 207:1157-1165.

32. Najarro K, Nguyen H, Chen G, Xu M, Alcorta S, Yao X, Zukley L, Metter EJ, Ferrucci L, Weng NP. 2015. Telomere Length as an Indicator of the Robustness of Band T-Cell Response to Influenza in Older Adults. J Infect Dis. 212(8):1261-1269.

33. Gonzalez-Serna A, Ferrando-Martinez S, Tarancon-Diez L, De Pablo-Bernal RS, Dominguez-Molina B, Jiménez JL, Muñoz-Fernández MÁ, Leal M, Ruiz-Mateos E. 2017. Increased CD $127^{+}$and decreased $\mathrm{CD} 57^{+} \mathrm{T}$ cell expression levels in HIV-infected patients on NRTI-sparing regimens. J Transl Med 20;15(1):259.

34. Wilson CM, Ellenberg JH, Sawyer MK, Belzer M, Crowley-Nowick PA, Puga A, Futterman DC, Peralta L. 2001. Adolescent Medicine HIV/AIDS Research Network. adolescents in the REACH cohort. Reaching for Excellence in Adolescent Care and Health. J Adolesc Health 29:123-129.

MG, Koziel MJ, Overton ET. 2011. Lower peripheral blood CD14+ monocyte 466 frequency and higher CD34+ progenitor cell frequency are associated with HBV vaccine induced response in HIV infected individuals. Vaccine 29:3558-3563. and its relationship with T CD45RA+ (naive) and CD45RO+ (memory) subsets in HIV- 
471 37. Ferrando-Martínez S, Ruiz-Mateos E, Romero-Sánchez MC, Muñoz-Fernández

472 MÁ, Viciana P, Genebat M, Leal M. 2011. HIV infection-related premature 473 immunosenescence: high rates of immune exhaustion after short time of infection. Curr $474 \quad$ HIV Res 9:289-294.

38. De Pablo-Bernal RS, Ramos R, Genebat M, Cañizares J, Rafii-El-Idrissi Benhnia

M, Muñoz-Fernández MA, Pacheco YM, Galvá MI, Leal M, Ruiz-Mateos E. 2016.

Phenotype and polyfunctional deregulation involving interleukin 6 (IL-6)- and IL-10producing monocytes in HIV-infected patients receiving combination antiretroviral therapy differ from those in healthy older individuals. J Infect Dis 213:999-1007.

39. Fisman DN, Agrawal D, Leder K. 2002. The effect of age on immunologic response to recombinant hepatitis B vaccine: a meta-analysis. Clin Infect Dis 35:1368-1375.

40. Fuster F, Vargas JI, Jensen D, Sarmiento V, Acuña P, Peirano F, Fuster F, Arab JP, Martínez F; Core-HIV Study Group. 2016. CD4/CD8 ratio as a predictor of the response to HBV vaccination in HIV-positive patients: A prospective cohort study. Vaccine 34:1889-1895.

41. Caby F, Guihot A, Lambert-Niclot S, Guiguet M, Boutolleau D, Agher R, Valantin

D, Katlama C. 2016. Determinants of a low CD4/CD ratio in HIV-1 infected individuals despite long term viral suppression. Clin Infect Dis 62:1297-1303. 
494 Table 1 Demographic, clinical and immunological variables associated with HBV vaccine responsiveness

\begin{tabular}{|c|c|c|c|}
\hline $\begin{array}{c}\text { Clinical and immunonological } \\
\text { variables }\end{array}$ & $n=41$ & $\begin{array}{c}\text { Unadjusted P value; } \\
\text { B }(95 \% \text { CI })\end{array}$ & $\begin{array}{c}\text { Adjusted P value; } \\
\text { B (95\% CI) }\end{array}$ \\
\hline Male sex, n (\%) & $31(76)$ & $0.055 ;-294.2[-595.5-7.1]$ & \\
\hline Age (years) & $41.0[33.5-46.5]$ & $0.717 ;-3.3[-21.3-14.8]$ & \\
\hline Nadir CD4 $^{+}$T-cell count $\left(\right.$cells $\left./ \mathrm{mm}^{3}\right)$ & $287.0[206.3-402.0]$ & $0.288 ; 0.46[-0.40-1.32]$ & \\
\hline $\mathrm{CD4}^{+}$T-cell count $\left(\right.$cells $\left./ \mathbf{m m}^{3}\right)$ & $703.0[553.0-887.5]$ & $0.302 ; 0.30[-0.28-0.88]$ & \\
\hline CD8 $^{+}$T-cell count $\left(\right.$cells $/ \mathbf{m m}^{3}$ ) & $643.0[501.0-927.0]$ & $0.344 ;-0.19[-0.58-0.21]$ & \\
\hline Ratio CD4 $^{+} / \mathrm{CD8}^{+}$ & $0.9[0.8-1.4]$ & $0.205 ; 139.1[-79.0-357.1]$ & \\
\hline Time since diagnosis (months) & $75.0[37.5-212.0]$ & $0.200 ; 0.89[-0.49-2.27]$ & \\
\hline Sexual transmission, $\mathbf{n}(\%)$ & $36(88)$ & $0.579 ; 114.4[-298.7-527.4]$ & \\
\hline Previous AIDS, n (\%) & $2(5)$ & $0.074 ;-548.2[-1152.6-56.3]$ & \\
\hline Previous HCV coinfection, $n(\%)$ & $5(12)$ & $0.453 ; 154.4[-257.3-566.0]$ & \\
\hline NRTI containing cART, $n(\%)$ & $18(44)$ & $0.496 ; 92.4[-179.4-364.2]$ & \\
\hline MVC containing cART, n (\%) & $21(51)$ & $0.017 ; 310.8[58.7-563.0]$ & $0.016 ; 293.3[58.1-5280.5]$ \\
\hline Previous HBV vaccination, $\mathrm{n}(\%)^{*}$ & $13(32)$ & $0.067 ; 262.6[-19.5-544.8]$ & \\
\hline $\begin{array}{l}\text { Simultaneous HAV vaccination, n } \\
(\%)\end{array}$ & $18(44)$ & $0.029 ; 287.9[31.0-545.0]$ & \\
\hline Time on HIV-treatment (months) & $69.5[38.0-178.8]$ & $0.376 ; 0.74[-0.93-2.42]$ & \\
\hline hsCRP (mg/L) & $0.8[0.5-1.3]$ & $0.096 ;-165.8[-362.4-30.9]$ & \\
\hline \% Lymphocytes & $35.6[26.1-39.2]$ & $0.555 ; 4.9[-11.7-21.4]$ & \\
\hline \% Monocytes & $5.6[5.3-6.1]$ & $0.393 ; 66.5[-89.5-222.4]$ & \\
\hline \% Neutrophils & $53.6[49.3-63.3]$ & $0.593 ;-3.7[-17.8-10.3]$ & \\
\hline$\% \mathrm{CD4}^{+}$Naives & $44.6[34.2-51.0]$ & $0.496 ; 3.2[-6.3-12.7]$ & \\
\hline$\% \mathrm{CD4}^{+} \mathrm{RTE}$ & $75.6[66.5-79.8]$ & $0.204 ; 9.2[-5.2-23.7]$ & \\
\hline$\%$ CD4 $^{+}$Central Memory & $28.3[23.2-39.5]$ & $0.791 ;-1.9[-16.7-12.8]$ & \\
\hline$\% \mathrm{CD4}^{+}$Effector Memory & $20.7[14.9-27.8]$ & $0.400 ;-6.1[-20.5-8.4]$ & \\
\hline
\end{tabular}




\begin{tabular}{|c|c|c|c|}
\hline$\% \mathrm{CD4}^{+}$TemRA & $1.8[1.1-4.3]$ & $0.154 ;-31.4[-75.2-12.3]$ & \\
\hline$\% \mathrm{CD4}^{+}$HLA-DR ${ }^{+}$ & $1.7[1.1-2.0]$ & $0.161 ;-128.1[-309.6-53.4]$ & \\
\hline$\% \mathrm{CD4}^{+} \mathrm{ki}^{+} 7^{+}$ & $2.3[2.1-2.7]$ & $0.053 ;-199.5[-401.4-2.5]$ & \\
\hline$\% \mathrm{CD4}^{+} \mathrm{CD57}^{+}$ & $4.7[3.1-8.0]$ & $0.825 ;-3.1[-31.3-25.2]$ & \\
\hline$\% \mathrm{CD4}^{+} \mathrm{CD}^{2} 5^{+}$ & $55.0[43.1-65.0]$ & $0.394 ;-3.7[-12.3-5.0]$ & \\
\hline$\% \mathrm{CD}^{+} \mathrm{CD}^{\mathrm{CD}^{\mathrm{hi}} \mathrm{FoxP3}^{+}}$ & $1.3[1.0-1.8]$ & $0.565 ;-64.7[-290.3-160.9]$ & \\
\hline$\% \mathrm{CD4}^{+} \mathrm{CD}^{25^{\mathrm{hi}} \text { FoxP3 }^{+} \mathrm{HLA}^{2}-\mathrm{DR}}{ }^{+}$ & $15.1[11.0-21.6]$ & $0.039 ;-19.7[-38.3--1.0]$ & \\
\hline 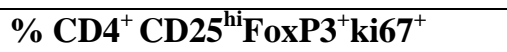 & $19.8[16.9-25.0]$ & $0.011 ;-28.9[-50.7--7.1]$ & $0.005 ;-29.6[-49.6--9.5]$ \\
\hline$\% \mathrm{CD4}^{+} \mathrm{CD}^{25^{\mathrm{hi}} \mathrm{FoxP3}^{+} \mathrm{CD}{ }^{+}}$ & $81.2[41.7-87.0]$ & $0.274 ;-2.9[-8.2-2.4]$ & \\
\hline 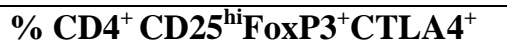 & $58.7[46.9-68.3]$ & $0.232 ;-5.9[-15.8-4.0]$ & \\
\hline$\%$ mDCs & $0.7[0.4-1.1]$ & $0.477 ;-85.4[-325.9-155.1]$ & \\
\hline$\%$ pDCs & $0.2[0.18-0.24]$ & $0.072 ; 1323.5[-122.5-2769.6]$ & $0.009 ; 1961.2[530.4-3392.0]$ \\
\hline
\end{tabular}

496 Continuous variables are expressed as median values [IQR] and categorical variables

497 are expressed as number of cases (\%). All demographic, clinical and immunological

498 variables with a $p$ value of $<0.1$ in the unadjusted model were included in the adjusted

499 model and are shown in bold. Hence, male sex, previous AIDS, MVC containing cART,

500 previous $\mathrm{HBV}$ vaccination, simultaneous $\mathrm{HAV}$ vaccination, hsCRP, \%CD4 ${ }^{+} \mathrm{ki} 67^{+}$,

$501 \% \mathrm{CD} 4^{+} \mathrm{CD} 25^{\mathrm{hi}} \mathrm{FoxP}^{+}{ }^{+} \mathrm{HLA}_{-\mathrm{DR}}, \% \mathrm{CD} 4^{+} \mathrm{CD} 25^{\mathrm{hi}} \mathrm{FoxP}^{+} \mathrm{ki}^{+} 7^{+}, \%$ pDCs were included in

502 the stepwise forward multivariate model. As shown, the resulting model only retained

503 the variables MVC containing cART, $\% \mathrm{CD} 4^{+} \mathrm{CD} 25^{\mathrm{hi}} \mathrm{FoxP}^{+}{ }^{+} \mathrm{ki} 67^{+}$and $\%$ pDCs.

504 Variables with a $p$ value of $<0.05$ in the adjusted model were considered statistically

505 significant and are shown in bold. 
bioRxiv preprint doi: https://doi.org/10.1101/298521; this version posted April 10, 2018. The copyright holder for this preprint (which was not certified by peer review) is the author/funder. All rights reserved. No reuse allowed without permission.

506 Table 2. Demographic, clinical and immunological variables associated with an 507 MVC-containing cART. 


\begin{tabular}{|c|c|c|c|c|}
\hline $\begin{array}{l}\text { Clinical and immunonological } \\
\text { variables } \\
(n=41)\end{array}$ & $\begin{array}{l}\text { MVC- } \\
\text { containing } \\
\text { cART } \\
(\mathrm{N}=21)\end{array}$ & $\begin{array}{l}\text { MVC-sparing } \\
\text { cART } \\
(\mathbf{N}=\mathbf{2 0})\end{array}$ & $\begin{array}{l}\text { Unadjusted } p \text { value; } \\
\text { OR }[95 \% \mathrm{CI}]\end{array}$ & $\begin{array}{l}\text { Adjusted } p \text { value; } \\
\text { OR }[95 \% \mathrm{CI}]\end{array}$ \\
\hline Male sex, n (\%) & $15(71)$ & $16(80)$ & $0.525 ; 0.625[0.147-2.659]$ & \\
\hline Age (years) & $36[31-44]$ & $44[39-48]$ & $0.024 ; 0.892[0.800-0.985]$ & $0.878 ; 1.01[0.87-1.18]$ \\
\hline $\begin{array}{l}\text { Nadir CD4 }{ }^{+} \text {T-cell count } \\
\left(\text { cells } / \mathrm{mm}^{3}\right)\end{array}$ & 294 [184-412] & 264 [206-379] & $0.539 ; 1.001[0.997-1.005]$ & \\
\hline $\mathrm{CD4}^{+} \mathrm{T}$-cell count $\left(\right.$ cells/mm $\mathbf{m}^{3}$ ) & 703 [565-869] & 725 [529-911] & $0.775 ; 1.000[0.997-1.002]$ & \\
\hline CD8 $^{+}$T-cell count $\left(\right.$cells/mm ${ }^{3}$ ) & $781[538-961]$ & 596 [491-829] & $0.109 ; 1.002$ [1.000-1.004] & \\
\hline $\mathrm{CD4}^{+} / \mathrm{CD8}^{+}$Ratio & $0.9[0.6-1.2]$ & $1.1[0.9-1.6]$ & $0.084 ; 0.309[0.082-1.170]$ & $0.086 ; 0.20[0.03-1.26]$ \\
\hline Time since diagnosis (months) & $65[32-212]$ & $132[67-235]$ & $0.158 ; 0.995[0.989-1.002]$ & \\
\hline $\begin{array}{l}\text { Time on HIV-treatment } \\
\text { (months) }\end{array}$ & $46[33-147]$ & $120[64-201]$ & $0.057 ; 0.992[0.984-1.000]$ & $0.105 ; 0.99[0.97-1.00]$ \\
\hline Sexual transmission. n (\%) & $18(86)$ & $18(90)$ & $0.677 ; 1.500[0.223-10.077]$ & \\
\hline Previous AIDS. n (\%) & $1(5)$ & $1(5)$ & $0.972 ; 0.950[0.055-16.293]$ & \\
\hline $\begin{array}{l}\text { Previous HCV coinfection. } n \\
(\%)\end{array}$ & $4(19)$ & $1(5)$ & $0.199 ; 4.471[0.454-44.011]$ & \\
\hline NRTI containing cART. n (\%)* & $4(19)$ & $14(70)$ & $0.002 ; 0.101[0.024-0.430]$ & \\
\hline hsCRP (mg/L) & $0.8[0.5-1.1]$ & $0.9[0.6-1.5]$ & $0.324 ; 0.612[0.231-1.623]$ & \\
\hline \% Lymphocytes & $35.6[25.8-38.6]$ & $35.2[26.8-40.6]$ & $0.962 ; 1.002[0.930-1.080]$ & \\
\hline \% Monocytes & $5.5[5.3-6.5]$ & $5.6[5.2-6.0]$ & $0.518 ; 1.271[0.614-2.630]$ & \\
\hline$\%$ Neutrophils & $54.3[49.6-64.0]$ & $53.6[49.2-62.5]$ & $0.996 ; 1.000[0.938-1.066]$ & \\
\hline$\% \mathrm{CD4}^{+}$Naives & $44.1[34.5-55.6]$ & $44.9[33.7-50.1]$ & $0.829 ; 0.995$ [0.954-1.039] & \\
\hline$\% \mathrm{CD4}^{+} \mathrm{RTE}$ & $78.0[69.9-82.5]$ & $69.3[64.3-76.4]$ & $0.016 ; 1.116[1.021-1.220]$ & $0.024 ; 1.20[1.03-1.41]$ \\
\hline$\% \mathrm{CD4}^{+}$Central Memory & $29.4[23.3-33.2]$ & $28.3[22.9-42.5]$ & $0.752 ; 0.989$ [0.926-1.057] & \\
\hline$\% \mathrm{CD4}^{+}$Effector Memory & $20.0[18.0-27.5]$ & $22.0[12.9-28.5]$ & $0.968 ; 0.999$ [0.936-1.065] & \\
\hline$\%$ CD4 $^{+}$TemRA & $2.4[1.1-4.3]$ & $1.6[0.8-4.4]$ & $0.873 ; 1.017[0.831-1.243]$ & \\
\hline$\%$ CD4 $^{+}$HLA-DR ${ }^{+}$ & $1.8[1.0-2.0]$ & $1.6[1.1-2.3]$ & $0.880 ; 1.066[0.464-2.451]$ & \\
\hline$\% \mathrm{CD}^{+} \mathrm{ki67}^{+}$ & $2.4[2.0-3.2]$ & $2.2[2.1-2.6]$ & $0.219 ; 1.629[0.748-3.547]$ & \\
\hline$\% \mathrm{CD}^{+} \mathrm{CD5}^{+}$ & $4.8[3.5-8.0]$ & $4.47[2.1-10.8]$ & $0.879 ; 0.990[0.873-1.124]$ & \\
\hline
\end{tabular}




\begin{tabular}{|c|c|c|c|c|}
\hline$\% \mathrm{CD4}^{+} \mathrm{CD}^{\circ} 5^{+}$ & $55.0[40.7-66.0]$ & $54.4[44.1-63.9]$ & $0.590 ; 1.011[0.971-1.052]$ & \\
\hline \% CD4 ${ }^{+} \mathrm{CD}^{25}{ }^{\text {hi }}$ FoxP3 $^{+}$ & $1.2[0.9-2.0]$ & $1.5[1.1-1.7]$ & $0.992 ; 0.995[0.358-2.765]$ & \\
\hline $\begin{array}{l}\text { \% CD4 }{ }^{+} \text {CD25 }^{\text {hi }} \text { FoxP3 }^{+} \text {HLA- } \\
\text { DR }^{+}\end{array}$ & $13.9[9.9-21.6]$ & $16.1[12.2-22.1]$ & $0.543 ; 0.973[0.889-1.064]$ & \\
\hline$\% \mathrm{CD4}^{+} \mathrm{CD} 5^{\mathrm{hi}} \mathrm{FoxP3}^{+} \mathrm{ki} 7^{+}$ & $18.5[13.5-25.2]$ & $20.1[17.6-25.0]$ & $0.216 ; 0.930[0.830-1.043]$ & \\
\hline 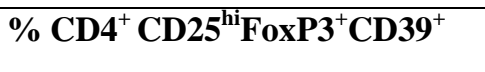 & $82.0[41.7-88.2]$ & $83.7[81.2-85.1]$ & $0.716 ; 1.005$ [0.980-1.029] & \\
\hline$\% \mathrm{CD4}^{+} \mathrm{CD25}^{\mathrm{hi}}$ FoxP3 $^{+} \mathrm{CTLA4}^{+}$ & $59.0[46.2-65.2]$ & $57.7[47.8-69.2]$ & $0.545 ; 0.986[0.941-1.032]$ & \\
\hline$\%$ mDCs & $0.5[0.3-0.8]$ & $0.8[0.6-1.4]$ & $0.042 ; 0.226[0.054-0.949]$ & $0.048 ; 0.16[0.03-0.98]$ \\
\hline$\% \mathrm{pDCs}$ & $0.2[0.1-0.2]$ & $0.2[0.1-0.3]$ & $0.529 ; 0.109$ [0.000-108.297] & \\
\hline
\end{tabular}

508 Continuous variables are expressed as median values [IQR] and categorical variables

509 are expressed as number of cases (\%). All demographic, clinical and immunological

510 variables with a $p$ value of $<0.1$ in the unadjusted model were included in the adjusted

511 model and are shown in bold. Hence, age, $\mathrm{CD} 4^{+} / \mathrm{CD}^{+}$ratio, time on HIV-treatment,

$512 \% \mathrm{CD} 4^{+} \mathrm{RTE}$ and $\% \mathrm{mDCs}$ were included in the enter multivariate model $(\mathrm{n}=38)$.

513 Variables with a $p$ value of $<0.1$ were showed in italics. Variables with a $p$ value of

$514<0.05$ in the adjusted model were considered statistically significant and are shown in

515 bold. *The absence of NRTIs was colineal with the presence of MVC, then, only the

516 second variable was included in the multivariate model. 
517 Table 3. Relation-ship between the time of exposure to an MVC-containing cART 518 and immunological variables.

\begin{tabular}{|c|c|c|}
\hline Immunonological variables $(n=21)$ & $\mathbf{r}$ & $\mathbf{p}$ \\
\hline hsCRP (mg/L) & 0.003 & 0.989 \\
\hline \% Lymphocytes & 0.068 & 0.769 \\
\hline \% Monocytes & -0.297 & 0.191 \\
\hline \% Neutrophils & -0.079 & 0.735 \\
\hline \% $\mathrm{CD4}^{+}$Naives & 0.185 & 0.434 \\
\hline$\% \mathrm{CD4}^{+} \mathrm{RTE}$ & -0.161 & 0.497 \\
\hline$\% \mathrm{CD4}^{+}$Central Memory & -0.151 & 0.526 \\
\hline$\%$ CD4 $^{+}$Effector Memory & -0.085 & 0.723 \\
\hline$\% \mathrm{CD4}^{+}$TemRA & -0.087 & 0.714 \\
\hline$\% \mathrm{CD4}^{+} \mathrm{HLA}^{-\mathrm{DR}^{+}}$ & -0.489 & 0.034 \\
\hline$\% \mathrm{CD4}^{+} \mathrm{ki67}^{+}$ & -0.477 & 0.029 \\
\hline$\% \mathrm{CD4}^{+} \mathrm{CD57}^{+}$ & 0.110 & 0.663 \\
\hline$\% \mathrm{CD4}^{+} \mathrm{CD}^{+} 5^{+}$ & -0.170 & 0.460 \\
\hline$\% \mathrm{CD4}^{+} \mathrm{CD}^{\mathrm{hi}}{ }^{\mathrm{hoxP3}}{ }^{+}$ & -0.523 & 0.015 \\
\hline$\% \mathrm{CD4}^{+} \mathrm{CD25}^{\mathrm{hi}}{ }^{\text {FoxP3 }^{+} \text {HLA-DR }}{ }^{+}$ & -0.126 & 0.586 \\
\hline$\% \mathrm{CD4}^{+} \mathrm{CD25}^{\mathrm{hi}} \mathrm{FoxP3}^{+} \mathbf{k i 6 7}^{+}$ & -0.318 & 0.172 \\
\hline$\% \mathrm{CD4}^{+} \mathrm{CD25}^{\mathrm{hi}} \mathrm{FoxP3}^{+} \mathrm{CD39}^{+}$ & 0.116 & 0.617 \\
\hline 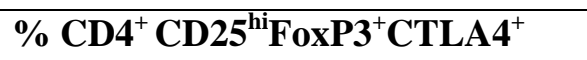 & 0.226 & 0.324 \\
\hline$\% \mathrm{mDCs}$ & -0.133 & 0.567 \\
\hline$\%$ pDCs & 0.105 & 0.650 \\
\hline
\end{tabular}




\section{$521 \quad$ Figure Legends}

522 Figure 1. Relationship between the time of exposure to an MVC-cART and

523 immunological variables. Only correlations with a $p$ value of $<0.1$ between the time of

524 exposure to an MVC-cART and different immunological variables are represented.

525 Figure 2. Associations between hsCRP and different T-cell immunological

526 variables. Only correlations with a $p$ value of $<0.1$ between hsCRP and several T-cell

527 immunological variables are represented. 
530

531

532

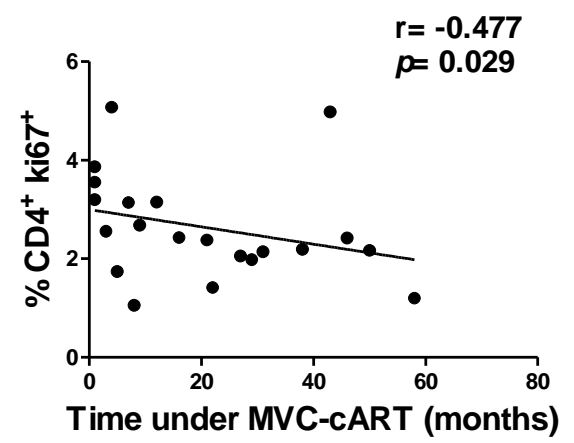

534

Figure 2

535

536

537

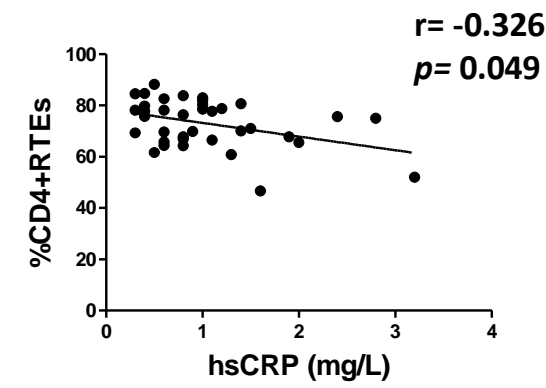

538

539

540

541
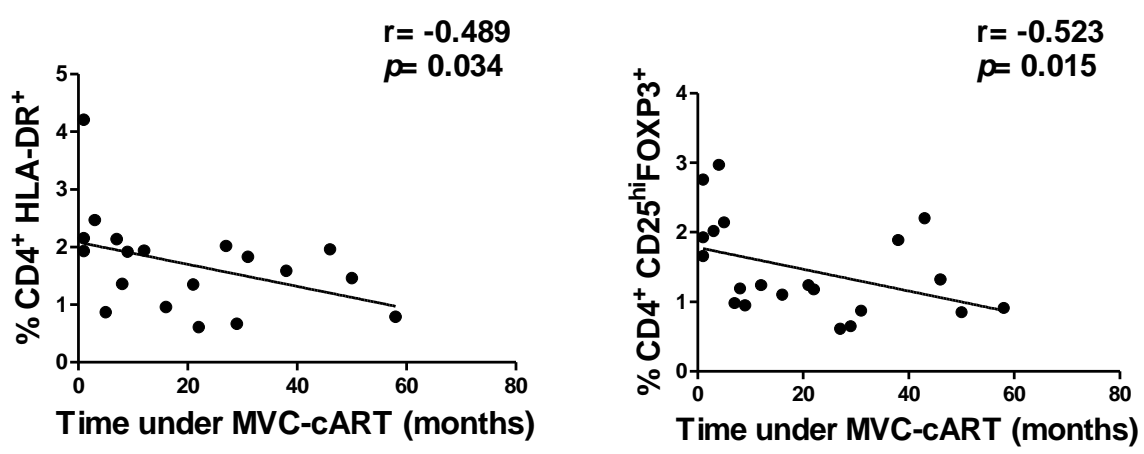
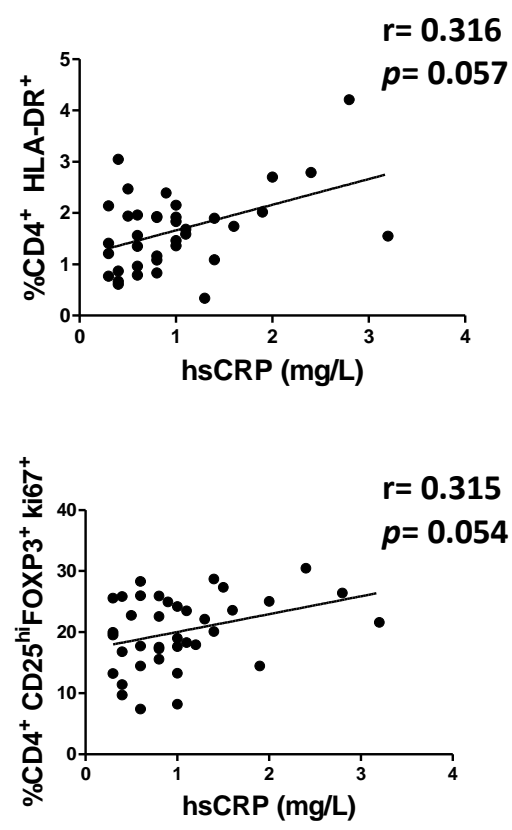